原著

\title{
椎骨動脈瘤に対する顆䆚経由法における開閉頭時の留意点
}

\author{
勝野亮, 山田 敏雅, 川崎 和凡, 稲葉泉
}

\section{The Pitfalls of the Transcondylar Fossa Approach for the Management of Vertebral Artery Aneurysm}

\author{
Makoto Katsuno, M.D., Toshimasa Yamada, M.D., Kazutsune KawasaKI, M.D., and \\ Izumi INABA, M.D.
}

Department of Neurosurgery, Dohtoh Forest Hospital, Kitami, Hokkaido, Japan

\begin{abstract}
Summary: Specific clipping for the treatment of a cerebral aneurysm is accomplished through a wide operative field. This is obtained through both full exposure and lateral exclusion of the sigmoid sinus; however, these increase the risk of either sigmoid sinus injury or occlusion. Here, we developed a transcondylar fossa approach with standardized procedures to improve surgical safety. Furthermore, we retrospectively analyzed the procedural outcomes. The most important steps of our approach include the following: layer-by-layer dissection of the suboccipital muscles, pealing of the emissary vein, exposure of the sigmoid sinus, opening of the dura, and closure of both the dura and mastoid air cell. A total of 12 patients underwent the mentioned transcondylar fossa approach for vertebral aneurysm treatment between 2014 and 2018. All aneurysms were successfully treated with our obliteration approach after surgery. However, one patient experienced sigmoid sinus occlusion as a result of excessive fat filling, which was associated with the closure of the mastoid air cells. In conclusion, our standardized procedures support safe clipping of vertebral artery aneurysms.
\end{abstract}

はじめに

近年の技術進歩により，椎骨動脈瘤に対して血管内手術 が第一選択になりつつある．しかし，動脈瘤の性状や分岐 血管の状態から開頭手術が適する症例も存在し, その際の アプローチに顆窩経由法 ${ }^{6)}$ がある。開頭手術で動脈瘤の処 置を確実に行うためには, 広く浅い術野を獲得する必要が あり，顆窩経由法では $\mathrm{S}$ 状静脈洞の露出が必須となる.

しかし，それを安全に行うには，開閉頭時の手技に注意を 要する. 今回, S 状静脈洞の露出ならびに温存に重点をお いた動脈瘤に対する顆窩経由法の連続症例を検討したため

\author{
Key words: \\ - transcondylar fossa \\ approach \\ - vertebral artery aneurysm \\ $\cdot$ sigmoid sinus
}

Surg Cereb Stroke

(Jpn) 48: 30-35, 2020

報告する．

道東の森総合病院 脳神経外科(受稿日 2018. 6. 6) (脱稿日 2018. 7. 17) 〔連絡先： ₹ 253-0083 神奈川県茅ヶ崎市西久保 500 湘南東部総合 病院 脳神経外科 勝野 亮] [Address correspondence: Makoto Katsuno, M.D., Department of Neurosurgery, Shonan Tobu Hospital, 500 Nishikubo, Chigasaki, Kanagawa 253-0083, Japan] 

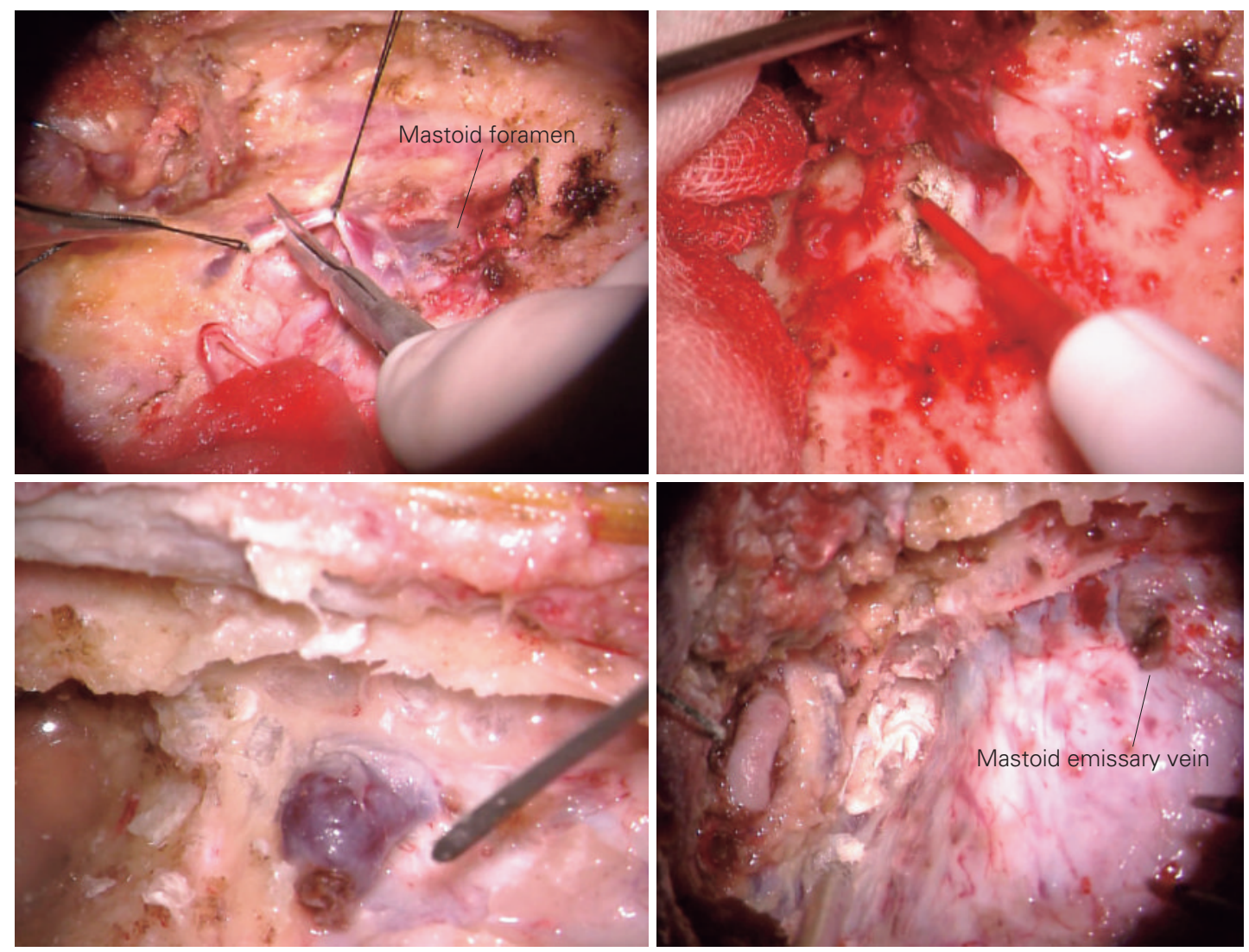

Fig. 1 Intraoperative photographs.
A $B$
A: The occipital vein is severed right before the mastoid foramen. B: The mastoid emissary vein is peeled off from the mastoid foramen under a bloodless condition. C: The mastoid foramen is opened without injuring the mastoid emissary vein. D The sigmoid sinus is widely exposed after drilling the condylar fossa.

\section{手 術 方 法}

\section{1. 体位}

患側上のパークベンチ体位とするが，患側の肩が術者に 干渉しないように腹臥位に近い状態とする。頭部は乳突切 痕が頂点となり, 頚静脈が圧迫されないように下顎を挙上 し，広く顆窩を露出するため頭頂部を下げて固定する。ま た，閉創時に腹部脂肪が採取できるように清潔野を設ける.

\section{2. 皮膚切開, 後頭下筋群の剝離, 頭蓋外椎骨動脈の確保}

皮膚切開は乳突切痕を頂点とし, 上端は外後頭隆起の上 方, 下端は第 2 頚椎で正中に基部をもつ逆 C 状に設ける. 皮弁を翻転後に, 上項線より頭頂側に位置する後頭筋を, 骨膜をつけた状態で一部を摘出し, 閉頭時まで保湿保存す る. その後に後頭動脈を温存しながら後頭下筋群を筋層ご とに顕微鏡下に剝離翻転するが, 詳細は他稿を参照された $\omega^{4)}$. この操作により浅く広い術野の獲得, 頭蓋外の椎骨 動脈の確保ならびに後述する導出静脈の無血的な処理を可
能とする．

\section{3. 乳突孔周囲の乳突導出静脈の処理}

後頭下筋群の筋層ごと剥離で, 後頭動脈に伴走する後頭 静脈の温存が可能となる。 その後頭静脈は, 乳突孔で乳突 導出静脈となるが, 乳突孔に流入する前で後頭静脈を焼灼 切断する(Fig. 1A)。 その断端を後頭骨の骨性骨膜ととも に乳突孔に収束するように剥離し(Fig. 1B)，後頭骨を完 全に露出する。これにより, 導出静脈の損傷なく断端の処 理が可能となり, 盲目的に乳突孔へ骨蝋を充填し導出静脈 からの出血に対応する操作は不要となる.

\section{4. 開頭, $S$ 状静脈洞の完全露出}

術前の検査で骨縫合線と静脈洞の位置関係を評価し, 骨 削除部が少なくなるように可能な限り大きな骨弁で後頭下 開頭を施行する。その際，前段階で処理した乳突導出静脈 の損傷を防止するため, その周囲へ開頭が及ばないように 配慮する. $\mathrm{S}$ 状静脈洞は, 乳突導出静脈との合流部で後頭 

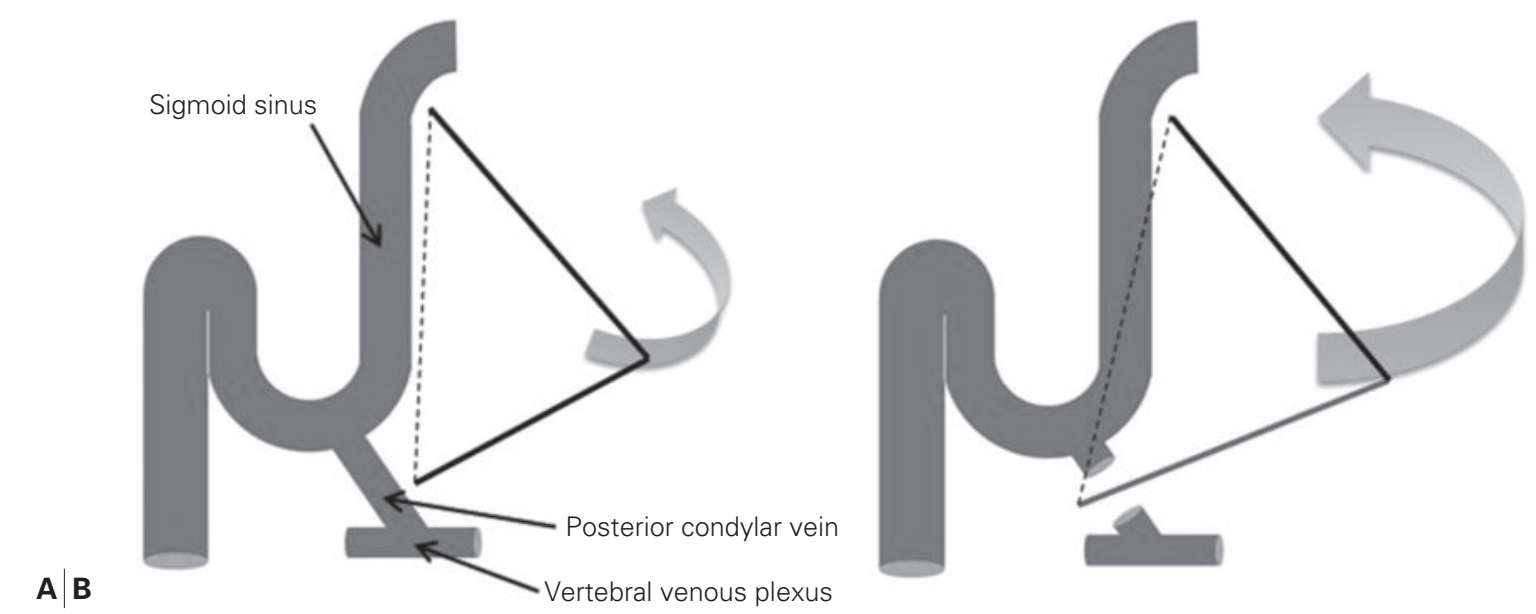

Fig. 2 Schema of the dura flaps, both before (A) and after (B) severing the posterior condylar vein.

骨との癒着が強固のため, 同部位での強引な硬膜の剝離操 作は，乳突導出静脈の引き抜け損傷を引き起こすため控え る.したがって, まず前段階で処理した乳突導出静脈の断 端を焼灼し短縮させ, 乳突孔内の乳突導出静脈を $\mathrm{S}$ 状静 脈洞に向けて剥離する。剥離された静脈は，骨蜕で乳突孔 内に押し込み, 静脈が剝離された部分の乳突孔を安全にド リルで開放する(Fig. 1C)。これらの操作を繰り返すこと で，無血かつ完全な乳突孔の開放と乳突導出静脈が合流す る $\mathrm{S}$ 状静脈洞までの安全な露出が可能となる，合流部以 外の S 状静脈洞は, 後頭骨内板を残す形で後頭骨表面を ドリルで削開する，同部位は後頭骨との癒着が疎のため, $\mathrm{S}$ 状静脈洞と後頭骨内板を剝離し，内板のみとなった後頭 骨を骨針子で除去する．S 状静脈洞を完全に露出すると， 大半の症例で乳突蜂巣が開放されるが，その閉鎖処置は閉 頭時に行うこととする。なお， S 状静脈洞の露出の上端は 病変の位置によるが, 破裂例では横静脈洞の移行部まで行 う。下端は S 状静脈洞が前方に方向を変える部位まで露 出させる。

\section{5. 顆窩の削開}

大後頭孔を開放した後に顆窝を削開していく，その際に 顆導出静脈を，前段階で露出させた頭蓋外椎骨動脈の周囲 に存在する椎骨静脈丵から焼灼離断し, 乳突導出静脈と同 様の手技で顆管から剥離後に，顆管を開放する，それによ り，安全に顆窩を削開することが可能となる，通常の椎骨 動脈瘤であれば，顆管を開放するまでの顆窩削開で十分な 術野獲得ができる(Fig. 1D)。しかし，正中に近い病変でさ らなる展開が必要なときは, 舌下神経管内の静脈 (anterior condylar emissary vein)が確認できるまで後頭骨の後頭顆 を削開した後に，頚静脈結節を可能な限り除去する.

\section{6. 硬膜切開}

硬膜切開は, 切開した硬膜弁で $\mathrm{S}$ 状静脈洞を側方へ圧 排し，側方からの術野を獲得できるように設ける。すなわ ち, 硬膜弁は $\mathrm{S}$ 状静脈洞に基部をもつ形で, 切開上端を 可能な限り静脈洞の際まで加える。切開下端は, 顆窩の削 開で露出された硬膜を，S 状静脈洞が水平部に移行する部 位まで切り込む(Fig. 2).

\section{7. 硬膜内操作}

前段階で得られた S 状静脈洞の完全露出ならびに $\mathrm{S}$ 状 静脈洞の側方への圧排により, 椎体骨後面と顕微鏡の光軸 が平行になることが可能となり, 正中方向に広く明るい術 野の獲得が可能となる (Fig. 3A)。 また，十分な顆窩の削 開により後下小脳動脈の tosillomedullary segmentへのバ イパスにあたっても広く浅い術野が獲得でき, 安全に施行 できる(Fig. 3B).

\section{8. 閉創}

開頭時に採取した骨膜付きの後頭筋を用いて，硬膜と骨 膜とで膜同士を確実に縫合する。また， S 状静脈洞の露出 の際に開放された乳突蜂巣には，腹部脂肪を充眞する。そ の腹部脂肪が逸脱しないようにチタンプレートで骨弁を固 定し, 後頭下筋群を筋層ごとに再建し, 手術終了とす る。なお，破裂例では術中に脳室ドレナージを挿入してい るが，それ以外の症例では腰椎ドレナージを含め挿入しな い.

\section{結 果}

本研究の結果を Table 1 に示す. 全例で $\mathrm{S}$ 状静脈洞を損 傷せずに完全露出が行われ，安全に手術が施行された，症 例 3 は, 椎骨動脈解離の遠位部が高位で正中を超えて存在 

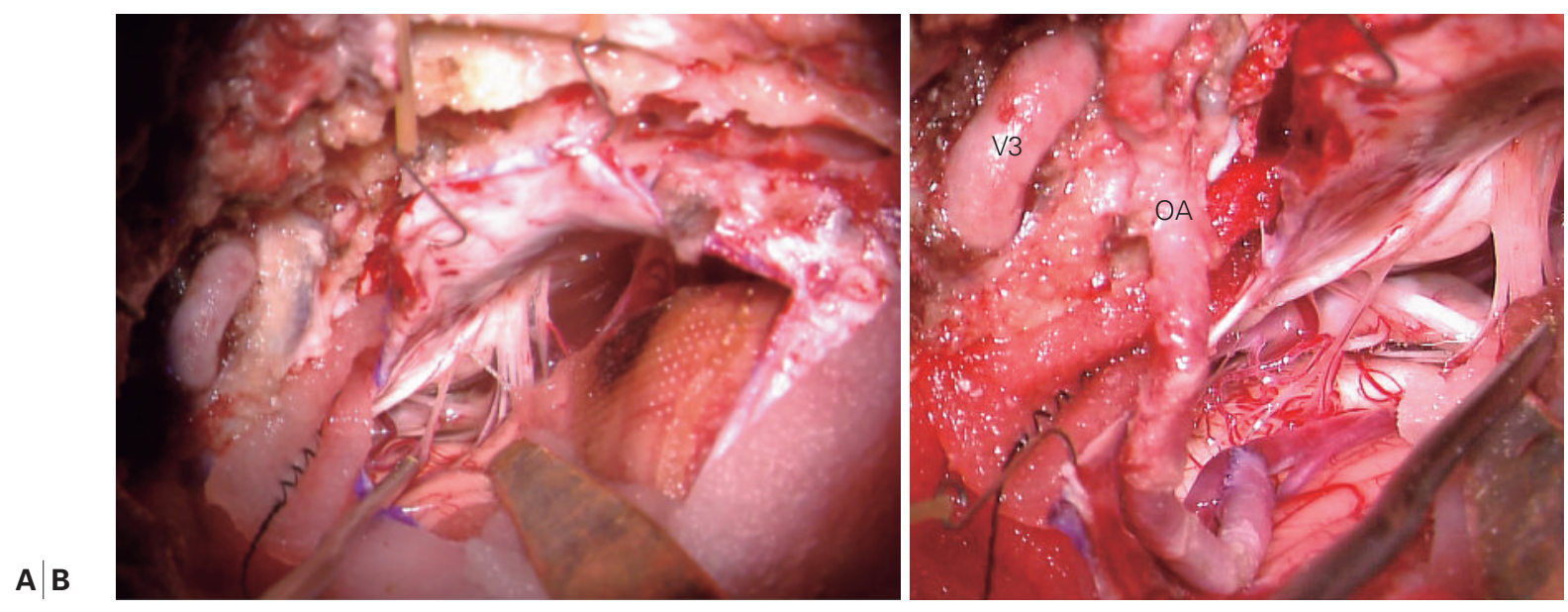

Fig. 3 A: A wide operative field is obtained through both full exposure and lateral exclusion of the sigmoid sinus. B: Sufficient drilling of the condylar fossa results in a wide anastomosis field for the posterior inferior cerebellar artery.

Table 1 Summary of patients' characteristics

\begin{tabular}{ccccccc}
\hline Case & Age/Sex & Aneurysm & Symptom & Surgery & OA-PICA bypass & Surgical complications \\
\hline 1 & $72 / \mathrm{M}$ & VA dissection & SAH & Clipping & - & - \\
2 & $46 / \mathrm{M}$ & VA thrombosis & Mass effect & Trapping & + & - \\
3 & $53 / \mathrm{M}$ & VA dissection & SAH & Proximal occlusion & + & - \\
4 & $53 / F$ & PICA dissection & SAH & Trapping & + & - \\
5 & $45 / F$ & VA-PICA true & SAH & Clipping & - & Sigmoid sinus occlusion \\
6 & $82 / F$ & VA-PICA true & SAH & Clipping & - & - \\
7 & $79 / F$ & VA-PICA true & SAH & Clipping & - & - \\
8 & $52 / M$ & PICA dissection & Infarction & Trapping & + & - \\
9 & $48 / F$ & VA-PICA true & SAH & Trapping & + & - \\
10 & $49 / M$ & PICA dissection & Infarction & Trapping & + & - \\
11 & $53 / F$ & VA dissection & Mass effect & Trapping & + & - \\
12 & $72 / F$ & VA-PICA true & SAH & Clipping & - & - \\
\hline
\end{tabular}

VA: vertebral artery, PICA: posterior inferior cerebellar artery, SAH: subarachnoid hemorrhage, OA: occipital artery

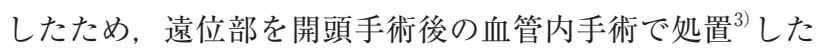
が, 全例で動脈瘤の消失を画像で確認した。また, バイパ ス施行例も, 全例で開存を確認した。髄液漏は存在せず, 外科手技に伴う有害事象として 1 例で術後に無症候性の S 状静脈洞閉塞が認められた。

\section{症例 提示}

\section{〈症例 5〉}

直径 $2.5 \mathrm{~mm}$ の左椎骨動脈上小脳動脈瘤破裂に伴うくも 膜下出血に対して開頭手術が選択され, 前述の手技が施行 された(Fig. 4A)。術中の S 状静脈洞損傷はなく, インド シアニン・グリーン血管撮影で $\mathrm{S}$ 状静脈洞の開存を確認 したが(Fig. 4B), 術後に術側の S 状静脈洞閉塞が確認さ れた (Fig. 4C). 乳突蜂巣の閉鎖目的に過充填された腹部脂
肪による圧迫が原因と判断された (Fig. 4D). 静脈の側副 血行路が発達していたため, 静脈梗塞の出現なく経過した.

\section{考察}

椎骨動脈瘤に対して顆窩経由法を使用する際に, 術野を 制限する頭蓋内構造物は, 小脳と S 状静脈洞である。し たがって, 広い術野を獲得するには, 小脳延髄裂などのく も膜を剝離し小脳の可動性を得ることと $\mathrm{S}$ 状静脈洞にも 可動性をもたせることが必要である，後者には，S 状静脈 洞の完全露出と切開した硬膜弁による効率よい $\mathrm{S}$ 状静脈 洞の圧排がさらに必要となる。本稿で記載した導出静脈の 処理を施行せずに $\mathrm{S}$ 状静脈洞の露出を試みていた以前 は, 導出静脈が $\mathrm{S}$ 状静脈洞に合流する部位の周囲の骨が 残存し, $\mathrm{S}$ 状静脈洞の完全露出が困難であった，本稿の手 

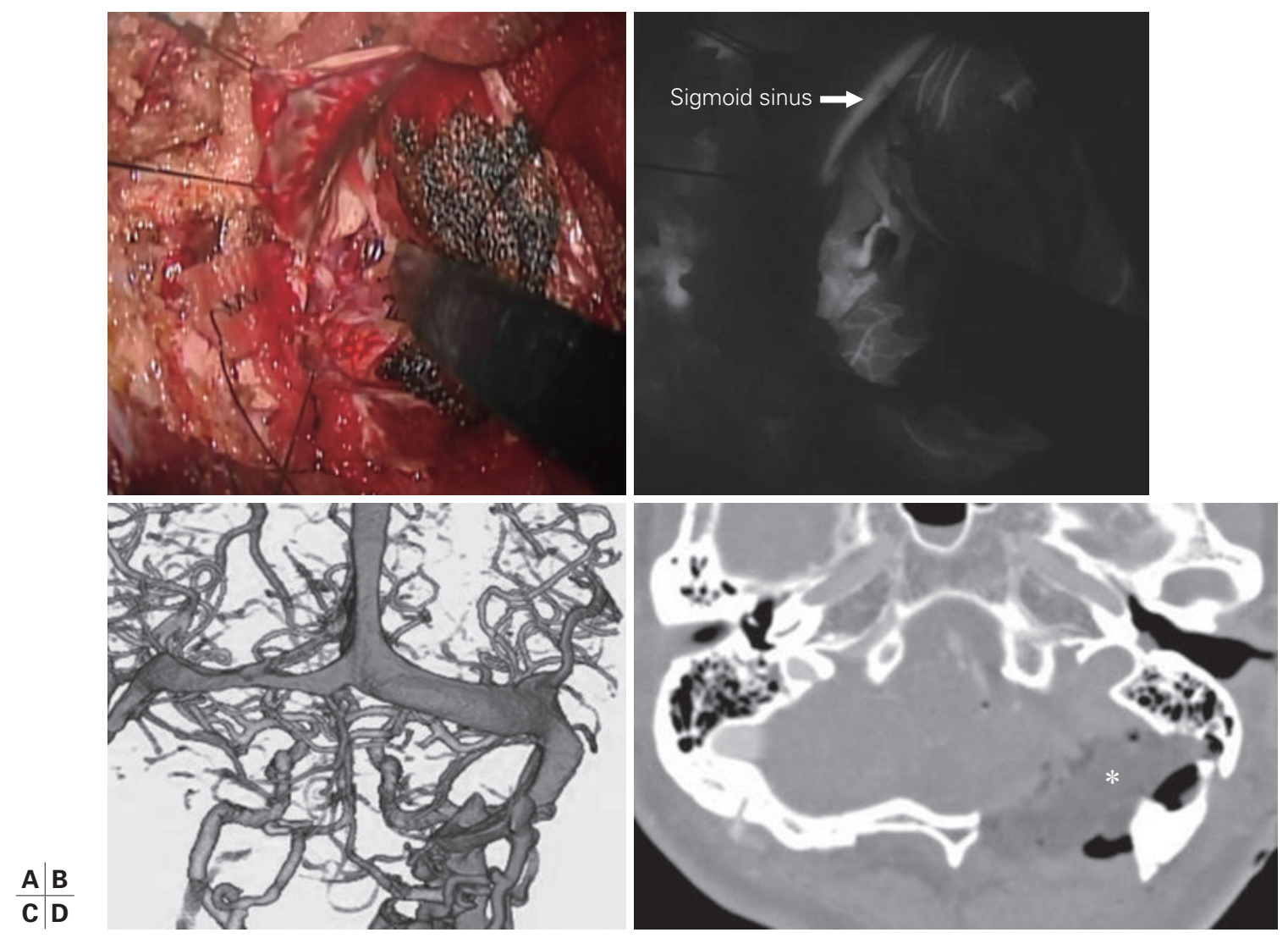

Fig. 4 Case 5:

A: The ruptured aneurysm is clipped with the left transcondylar fossa approach. B: Indocyanine green angiography shows good patency of the left sigmoid sinus after the clipping of the aneurysm. C: Postoperative computed tomography angiography displays an occlusion of the left sigmoid sinus. D: Postoperative computed tomography illustrates a compression of the left sigmoid sinus due to excessive abdominal fat $\left({ }^{*}\right)$.

技で $\mathrm{S}$ 状静脈洞を完全露出し, 硬膜切開の下端を $\mathrm{S}$ 状静 脈洞が水平部に移行する部の下方まで行うことで，硬膜弁 で効率よく S 状静脈洞を圧排することが可能となった.

しかし,これらの手技に扔いては, 導出静脈の処理に伴 う $\mathrm{S}$ 状静脈洞の損傷，開放される乳突蜂巣の閉鎖不全な らびに硬膜の閉鎖不全の可能性があるため注意が必要であ る.

まず，導出静脈の処理に伴う S 状静脈洞の損傷を防止 するために, 導出静脈の走行をあらかじめ把握しておく必 要がある. 乳突導出静脈の多くは S 状静脈洞に流出する. 顆導出静脈は, その多くが内頝静脈や $\mathrm{S}$ 状静脈洞に流出 するが，舌下神経管内の静脈 (anterior condylar emissary vein) や後頭静脈洞に流出するものが少数ながら存在す る7). したがって, 顆導出静脈の剝離は, 流出する静脈洞 まで全例で剥離する必要はない。その範囲は，S 状静脈洞 が水平部に移行した変曲点に向けて硬膜切開が行えるよう な，十分な骨削開が可能となるまでに留めておく，それに
より無駄な静脈洞損傷を抑えることができる，また，静脈 洞の閉塞を回避するには骨蝋の使用方法にも注意を要す る。すなわち, 発達した導出静脈からの出血に骨渢が使用 される場合があるが，開放した導出静脈から骨蜕が静脈洞 内に迷入し, 静脈洞閉塞が生じた報告 ${ }^{122}$ がある。したがっ て, 本稿で記載したように, 導出静脈の断端を焼灼閉鎖し た後に，骨蝋を使用するべきである．

次に, 開放した乳突蜂巣に対する処置は，その閉鎖目的 にも骨蝻が使用される場合があるが，それにより肉芽腫形 成をきたした報告 ${ }^{5}$ がある。したがって，本稿では骨蝋の 代わりに腹部脂肪を用いて対応したが, その充填方法に注 意が必要である。すなわち, 導出静脈を処理後に S 状静 脈洞を完全露出すると, S 状静脈洞内の血液量が減少する ことと骨からの洜離により S 状静脈洞の支持性が亯失す ることから， S 状静脈洞は容易に外力で閉塞しやすい状態 に陥る.したがって, 脂肪充填の際には, 開放された乳突 蜂巣のみに充填し, 近接する $\mathrm{S}$ 状静脈洞へ圧迫が加わらな 
いように配慮する必要がある.

最後に, 術後の硬膜縫合不全を防止するため, 確実な硬 膜閉鎖と, 開頭により生じた死腔を埋めることが必要であ る.ただし，過度の死胫閉鎖は，S 状静脈洞の閉塞を生じ させるため, 確実な硬膜縫合を主軸として対応する必要が ある，そのため, 硬膜を一次縫合するのではく, パッチを 使用し確実に硬膜縫合を行う。その際には, パッチ縁を硬 膜下に引き込み, パッチの採取時に温存した骨膜と硬膜断 端の膜同士を確実に縫合する必要がある.

\section{結語}

顆窩経由法で広範な術野を獲得するには，S 状静脈洞を 完全に露出し，それを効率よく圧排する必要がある。それ により確実な手術手技が可能となる。本稿の各手技は，革 新的ではないが, 後頭下筋群の筋層ごとの剝離, 導出静脈 の処理，後頭骨の削開，硬膜切開そして硬膜と開放された 乳突蜂巣の閉鎖まで細かな手技を含め確実に行うこと が，より安全で確実な手術を可能とする。

著者全員は日本脳神経外科学会への COI 自己申告を完 了しています。本論文の発表に関して開示すべきCOI は ありません。

\section{文献}

1) Crocker M, Nesbitt A, Rich P, et al: Symptomatic venous sinus thrombosis following bone wax application to emissary veins. Br J Neurosurg 22: 798-800, 2008

2) Hadeishi H, Yasui N, Suzuki A: Mastoid canal and migrated bone wax in the sigmoid sinus: technical report. Neurosurgery 36: 1220-1223, 1995

3) Katsuno M, Matsuno A: Aneurysm trapping by both direct and endovascular surgery for vertebral artery dissection: A case report. Surg Neurol Int 9: 10, 2018

4) Katsuno M, Tanikawa R, Uemori G, et al: Occipital artery-toposterior inferior cerebellar artery anastomosis with multiple-layer dissection of suboccipital muscles under a reverse C-shaped skin incision. Br J Neurosurg 29: 401-405, 2015

5) Low WK, Sim CS: Bone wax foreign body granuloma in the mastoid. ORL J Otorhinolaryngol Relat Spec 64: 38-40, 2002

6) Matsushima T, Natori Y, Katsuta T, et al: Microsurgical anatomy for lateral approaches to the foramen magnum with special reference to transcondylar fossa (supracondylar transjugular tubercle) approach. Skull Base Surg 8: 119-125, 1998

7) Ota N, Tanikawa R, Yoshikane T, et al: Surgical Microanatomy of the Posterior Condylar Emissary Vein and its Anatomical Variations for the Transcondylar Fossa Approach. Oper Neurosurg (Hagerstown) 13: 382-391, 2017 